\title{
The impact of voluntary management earnings forecasts on executive compensation contracts
}

\author{
Kenneth Venmans ${ }^{1}$
}

\begin{abstract}
This study attempts to find a relationship between management earnings forecasts and executive compensation contracts. It focuses on three different elements of management earnings forecasts, namely: the type of forecast, the actual expectation of the forecast and the forecasting frequency. The three relations are analysed through both logistic and linear regressions using a sample of 90 U.S. listed companies between 2006 and 2012. From the analysis, three conclusions can be drawn. First, companies do not always align the measures of their forecasts with the compensation measures used in executive compensation contracts. Second, the target levels used in management earnings forecasts and compensation contracts sometimes differ significantly, depending on the type of measure. Finally, the forecasting frequency of a company does not influence the type of compensation measures used. In general, it appears that earnings forecasts hold some relation to executive compensation contracts. Future research can further investigate this relationship, for example by focusing on the causes of the results or through replicating the analysis.
\end{abstract}

\section{Introduction}

Information asymmetry is an important concern for shareholders. Due to agency problems, managers may not act in their best interests. One example of such behaviour is the pay out of excessive compensation. In recent years, compensation and bonuses paid to executives made the headlines of Dutch newspapers. Examples include executives of ABN Amro in March 2015, as well as Vestia executive Erik Staal (König, 2012; v.d. Hulst, 2015). However, this problem is not limited to the Netherlands. In the United States, for example, executive compensation has received a significant amount of attention. Part of this attention was driven by high-profile scandals such as Tyco and more recently HSBC (Longnecker \& Krueger, 2007; Thompson, 2013). As a result of such scandals, many have called for changes in regulations. By increasing the transparency of the companies, the information asymmetry between shareholders and executives can be reduced. In the United States, the Securities Exchange Commission (SEC) has responded to these calls. At the end of 2006, it released new guidelines for all U.S. listed companies with respect to the disclosure of, among others, executive compensation (Kohn \& Fisher, 2007). These new rules require a complete breakdown of the executive's compensation package as designed by the compensation committee in a way that is easily understood by shareholders. Furthermore, an explanation must be provided on the rationale behind the actual compensation package that was chosen (Longnecker \& Krueger, 2007). Although it is mandatory for listed companies to disclose compensation information on all executives, this paper solely focuses on the compensation measures and targets of the CEO of the company.

Another type of information asymmetry exists with respect to future results. Executives often have more information about the company's expected performance because of insider information. Management can reduce this information asymmetry by releasing earnings forecasts (Diamond \& Verrecchia, 1991). This paper follows the definition of King, Pownall, and Waymire (1990), which defines management

\footnotetext{
${ }^{1}$ Kenneth Venmans received a bachelor degree in International Business at Maastricht University in 2015. He expects to continue his studies by pursuing a Master in International Business at Maastricht University starting September 2016. Contact: Kenneth_venmans@hotmail.com
} 
earnings forecasts as voluntary earnings forecasts made prior to the release of results. In general, these forecasts are made on a quarterly or annual basis and include either qualitative or quantitative expectations about the earnings per share (EPS) of the company. However, it is not uncommon for earnings forecasts to include additional information, such as expectations on revenues and other items from the income statement (Lansford, Lev, \& Tucker, 2007). The information in earnings forecasts is used by both analysts and shareholders and can have a significant impact on both the forecast of an analyst and the share price of the company (Baginski \& Hassell, 1990; Pownall, Wasley, \& Waymire, 1993).

It is interesting to investigate if a relation exists between these methods to reduce information asymmetry. For example, do firms use the same measures for their forecasts and executive compensation packages? Do firms that release earnings forecasts also provide a more detailed disclosure of their executives' compensation? That is the focus of this research. The research question of this paper is as follows:

What is the relationship between executive compensation contracts and voluntary management earnings forecasts?

Given that little research has been done on the relation between management earnings forecasts and executive compensation targets, this research adds to existing literature by attempting to establish a link between the two. Furthermore, only a few companies have used the new SEC disclosure requirements as a source of data (e.g. D. S. Kim and Yang (2010); S. Kim and Shin (2014). Therefore, this paper also contributes to existing literature by making use of the 2006 SEC additional disclosure requirements.

The remainder of this paper is structured as follows. First, the next section describes the available literature on both topics. Second, section three is used to develop several hypotheses. This is followed by a description of the methodology of this research, including the collection of data and the types of tests that are used. Afterwards, section five continues with the results of the analysis. Section six provides a discussion of the results. Finally, this paper concludes with a summary of the main points of this paper, its implications, the limitations of this research and suggestions for future research.

\section{Literature Review}

Plenty of research has been done on both executive compensation and management earnings forecasts. This section will provide an overview of available research on both topics. It starts with a discussion of the available literature on executive compensation. It continues with an overview of the literature on management earnings forecasts. The third part of this section discusses the available research that has attempted to link management earnings forecasts and executive compensation.

Before starting the literature review, some notes concerning the use of terms must be made. First, the words 'executive compensation contract', 'compensation package' and similar words refer to the compensation contract of the CEO of a company. This is because this research solely focuses on CEO compensation. Second, the use of 'earnings forecasts' and 'forecasts' throughout this paper refers to the 
definition of King et al. (1990) as mentioned in the introduction. Furthermore, earnings forecasts in this paper can refer to any type of forecast and is not limited to those focusing on EPS. Finally, the words 'measure' and 'type' refer to the different ways a company uses to compensate their executives. The word 'target' is used for both the compensation measure and the actual values associated with an earnings forecast or compensation contract. Similarly, the word 'target level' and 'level' also refer to the actual values associated with the two documents.

\subsection{Executive compensation and the new SEC regulation}

Research on executive compensation can be divided into multiple parts. One part focuses on executive compensation in relation to earnings management. For example, Gore, Pope, and Singh (2007) find that the amount of firm years where performance was just below target is significantly lower than expected. In contrast, the amount of firm years with performance at or just above target significantly exceed expectations. This indicates that earnings management occurs frequently to achieve targets.

After 2006, another part of the research on executive compensation has focused on the effects of the new regulation on executive compensation disclosure. For example, Longnecker and Krueger (2007) investigate the short- and long-term effects of the new regulation on executive compensation. For the short-term, they have two findings. First, they expect an increase in the relation between pay and performance because shareholders get a better insight in the compensation packages of executives. As a result, they will likely demand a better alignment between pay and performance. Furthermore, perks offered to executives will receive increasing scrutiny as the threshold for disclosure has been lowered to $\$ 10,000$. In the long run, Longnecker and Krueger (2007) expect an increase in both transparency and the amount of executive compensation. This is because companies now have to disclose how they designed their compensation packages, providing investors with a better insight in the company's compensation processes. However, other companies also have access to this information and are able to compare information on compensation. This is expected to pressure on companies to increase the pay of their executives to match the compensation of their peers.

However, not everyone is convinced of the usefulness of the new SEC regulations. For example, Donahue (2008) provides several reasons why the new regulations will not result in the complete disclosure of information. First, he argues that compensation consultants have an incentive to support management's compensation proposals to maintain the company as clients in upcoming years. The second argument is that companies maintain the right of not disclosing compensation information if this is deemed of competitive importance. Finally, full disclosure will not be achieved under the new rules because companies do not have to disclose perquisites awarded to executives below the value of $\$ 10,000$. Based on these three arguments, Donahue (2008) concludes the new rules will not lead to full disclosure. Similarly, Frantz, Instefjord, and Walker (2013) argue that disclosure does not always achieve the goal of providing better information. In contrast, their model, which takes into account several disclosure situations, suggests that it is more beneficial to both managers and shareholders to agree not to disclose anything.

Finally, two papers were found that have used the new disclosure requirements as a source of data. First, S. Kim and Shin (2014) use the EPS targets used in executive compensation contracts to 
investigate target ratcheting. After collecting data on the EPS targets for three consecutive years, they compare these targets with the actual result to determine the level of target ratcheting by the company. Second, an unpublished working paper by D. S. Kim and Yang (2010) focuses on the relation between the level of annual incentive targets and the actual results. Their research also builds on the new SEC regulations by obtaining data from the disclosure of compensation targets by companies. In contrast to S. Kim and Shin (2014), their research not only uses EPS targets, but also considers revenue, gross margin and net income targets. This research will use a similar approach by using performance goals from compensation contracts. The main difference between this research and the previously mentioned papers is that it uses this data to investigate the relation between this data and the information disclosed on management earnings forecasts.

\subsection{Management earnings forecasts}

Similar to the new disclosure requirements, a large number of research has focused on management earnings forecasts. Hirst, Koonce, and Venkataraman (2008) provide an overview of the existing studies on management earnings forecasts and divides them into three parts. The first part focuses on the reasons for disclosing information. Apart from reducing information asymmetry, releasing management earnings forecasts also has been found to reduce the cost of capital through a reduction in bid-ask spreads (Coller \& Yohn, 1997). Furthermore, companies that frequently release earnings forecasts were also found to raise money from capital markets more often than companies with infrequent or no forecasts (Frankel, McNichols, \& Wilson, 1995). The third category focuses on the outcomes of and market reactions on the forecasts (e.g. Baginski and Hassell (1990); Pownall et al. (1993); Rogers and Stocken (2005).

However, this research focuses on the second category of research: the characteristics of the earnings forecasts. This category can again be divided in several subsections. These categories include the type of news, the accuracy, form, horizon and level of disaggregation of the forecast. The type of news disclosed in management earnings forecasts depends on the expectations of the market. They can either exceed, confirm or fall short of the market expectations (Hirst et al., 2008). Although initially firms often used management earnings forecasts to communicate good news, more recent studies show that nowadays forecasts are more likely to convey bad news than good news (Hutton \& Stocken, 2007). Furthermore, the time horizon of earnings forecasts have been found to vary. Because the forecasts are of a voluntary nature, managers have the freedom to pick the time horizon of their forecasts. However, in general forecasts are either made on a quarterly or annual basis (Hirst et al., 2008). In recent years, a trend can be distinguished among the time horizon of management earnings forecasts. An increasing amount of companies has started to rely on annual forecasts, whereas fewer companies choose to release a quarterly forecast (National Investor Relations Institute, 2006). This result has been attributed to investors becoming increasingly concerned about management using the forecasts to affect the expectations of analysts (CFA Institute, 2006). Finally, other researchers focus on the level of disaggregation of the forecasts. Whereas some forecasts only disclose expected EPS, others also include expectations on revenue and cost of goods sold (Hirst et al., 2008). Multiple researchers find that about one in three forecasts include disaggregated information (e.g. Lansford et al. (2007) and Hirst, Koonce, and Venkataraman (2007)). Lansford et al. (2007) also provide several reasons why management may 
desire to disaggregate their forecasts. For example, disaggregation increases the reliability of the forecast and provides more useful information to users who are not interested in EPS expectations.

Another important topic within the characteristics of management earnings forecasts is the accuracy of the forecasts. This topic includes how the forecasts compare to actual outcomes, what influences forecast accuracy and strategic disclosure of forecasts. For example, Chen (2004) finds that quarterly earnings forecast are met almost half of the time. In contrast, Kasznik (1996) finds that companies achieve or exceed their annual earnings forecasts less than $10 \%$ of the time. Furthermore, Chen (2004) also finds that companies with higher systematic risk issue less accurate forecasts, as well as less experienced managers In addition, Yhim, Karim, and Rutledge (2003) find that the quality and precision of management earnings forecasts increase if the firm is largely held by outside shareholders. Finally, the forecasts issued by companies are often more precise if the volatility of its earnings are lower (e.g. Hassell, Jennings, and Lasser (1988); Yhim et al. (2003). This can be explained through the notion that it is easier to predict earnings if they are unlikely to vary relative to previous years.

In terms of strategic disclosure, evidence is mixed depending on the period of the research and the length of the earnings forecast. Early research on the topic did not find the existence of any significant bias in earnings forecasts in the early 1990s (Johnson, Kasznik, \& Nelson, 2001). In contrast, Chen (2004) finds a downward bias in quarterly earnings forecasts between 1994 and 2003. This is often explained by management's desire to lower the market's expectations of the firm's performance. In turn, this makes it easier for management to beat the forecasts. However, this evidence does not hold for annual earnings forecasts. Bergman and Roychowdhury (2008) find that managers do not wish to suppress optimistic forecasts by analysts through their long-term forecasts. Finally, the existence of bias in the earnings forecasts of a firm is also influenced by various factors. These factors include the overconfidence by management, the quality of corporate governance within the firm and the difficulty to detect bias (e.g. Karamanou and Vafeas (2005); Rogers and Stocken (2005).

\subsection{Executive compensation in relation to management earnings forecasts.}

Despite plenty of research on both topics, little research has attempted to identify a relation between the two topics. The research that has attempted to establish a relation between both topics often focuses on the relation between equity compensation and management earnings forecasts. For example, Nagar, Nanda, and Wysocki (2003) find that managers are more likely to issue earnings forecasts if equitybased compensation forms a larger part of their total compensation. These finding are closely related to results of previous research. For example, Marquardt and Wiedman (1998) find that managers are more likely to issue earnings forecasts around seasoned equity offerings. This is explained by a desire of management to reduce information asymmetry if they are selling their own shares. In contrast to Nagar et al. (2003) and Marquardt and Wiedman (1998), this research focuses on annual cash incentives. Therefore, this research contributes to existing literature by attempting to identify a relationship between cash incentives and voluntary management earnings forecasts. 


\section{Hypotheses Development}

To determine the relationship between management earnings forecasts and disclosure of executive compensation, this section develops several hypotheses. For all of the hypotheses presented in this section, it is assumed that the design of compensation contracts are influenced by the measures, levels or frequency of the management earnings forecasts made by a company. The rationale for this is that earnings forecasts are by definition forward looking and are often made in the year that precedes the relevant fiscal year (Hirst et al., 2008). In contrast, the compensation contracts are often established at the start of the relevant fiscal year. Furthermore, the filings used by companies to disclose their compensation packages are made several months after the relevant fiscal year.

The first hypothesis focuses on the type of targets that are disclosed in compensation contracts and their relation to the earnings forecasts. Management earnings forecasts generally include an expectation of the company's EPS for the end of the relevant fiscal year. In about one out of three times, these forecasts are disaggregated into various accounts or use different measures such as sales or gross profit margin (Lansford et al., 2007). Because management earnings forecasts contribute to the expectations of the market, the company has an incentive to ensure that these targets are met (Nagar et al., 2003). Failure to meet expectations is punished by the market through a drop in share price. To avoid such failures, it is important that management will focus on the measures of the expectations. Basic agency theory suggests that this can be achieved by tying management's compensation to the performance on the relevant measures. Therefore, it can be expected that companies attempt to align their executive's compensation packages with their earnings forecasts. This leads to the first hypothesis:

H.1: Companies tend to align the type of measures used in earnings forecasts and compensation contracts.

Similarly, the relation between the level of the earnings forecasts and the target level can be investigated. Relative to the expectation in an earnings forecast, compensation contracts can be set in three different ways: exceeding the expectation, equal to the expectation or below expectation. In a study by Bergman and Roychowdhury (2008), annual earnings forecasts were found to include an optimistic bias to positively influence the company's share price. Furthermore, previous research provides evidence that companies often were unsuccessful in achieving their targets. For example, Kasznik (1996) found that the targets disclosed in annual earnings forecasts were met or exceeded in less than $10 \%$ of the cases. This strengthens the notion that companies purposely introduce a positive bias in their earnings forecasts. However, it may not be wise to include this bias in the compensation contracts of executives. Because the targets will be difficult to achieve due to the bias, it is possible that such forecasts provide an executive with strong incentives for earnings management to achieve these targets. Therefore, it can be expected this bias is taken into account when creating a compensation contract. This leads to the second hypothesis:

H.2: Companies tend to use lower target levels for their executive compensation contracts relative to the target levels in their earnings forecasts. 
Furthermore, the composition of executive compensation contracts is of interest in this research. In general, the use of multiple measures is preferred relative to using a single measure. The underlying argumentation here is that every single performance measure has its own flaws. By combining multiple measures, it is possible to compensate for these flaws (Weiner \& Mahoney, 1981). In addition, Jusoh, Ibrahim, and Zainuddin (2008) find that the use of both financial and non-financial performance measures lead to better performance. Therefore, it appears that both the use of multiple financial measures and the use of a combination of financial and non-financial compensation measures are preferable over the use of a single measure.

Furthermore, a major motivation of publishing earnings forecasts is the creation of a reputation of transparency (Graham, Harvey, \& Rajgopal, 2005). In addition, the frequency and level of detail of disclosing management earnings forecasts has been associated with good corporate governance practices and is generally preferred by shareholders (Ajinkya, Bhojraj, \& Sengupta, 2005). As a result, it can be expected that companies that wish to maintain a reputation for transparency through their forecasts are also more likely to design compensation contracts according to the wishes of their stakeholders. Therefore, the following hypotheses can be established:

H.3.1: Companies that more frequently publish earnings forecasts are more likely to use multiple financial compensation measures.

H3.2: Companies that more frequently publish earnings forecasts are more likely to use a combination of financial and non-financial compensation measures.

\section{Methodology}

To test the hypotheses, various data has been collected on both management earnings forecasts and executive compensation contracts. The population for this research consists of all listed companies in the United States, because the new regulations only apply to companies that are regulated by the SEC. From this population, a sample consisting of 90 randomly selected companies was chosen. Furthermore, this research focuses on the years 2006 to 2012, resulting in a total of 461 firm year observations.

\subsection{Data collection}

Data on executive compensation contracts has been obtained from the DEF 14A filings of all companies that have been included in the sample. The DEF 14A filings have become mandatory after the change in regulations in 2006 and require companies to include a compensation discussion and analysis section. This section details the level of compensation as well as the process used to design the compensation contracts. The filings can be accessed through the SEC's Electronic Data-Gathering, Analysis and Retrieval system (EDGAR). From these filings, data has been retrieved on annual non-equity incentive compensation for the CEOs of the companies in the sample. This data includes the height of the base salary and cash compensation in each fiscal year. Furthermore, the dataset contains information on the type of targets used by companies and the weights attached to these targets. If available, the level of the target has also been recorded. Finally, data has also been collected on whether companies use non- 
financial or subjective targets, as well as the percentage of financial targets and non-financial targets that make up the executives compensation contract.

Data on management earnings forecasts has been retrieved from the I/B/E/S Guidance database. The data includes all management earnings forecasts that have been published by the companies in the sample with an ending date between 2005 and 2013. Furthermore, the dataset contains the type of earnings forecast. For example, it distinguishes between quarterly, annual and semi-annual forecasts. In addition, the dataset also specifies what variable was used. These variables include EPS, sales and gross profit margin, among others. Finally, the dataset also provides information about the level of the forecasts, including the level of the variable of interest at the time the forecast was made.

Several changes were made to this dataset. First, all earnings forecasts for the fiscal years 2005 and 2013 were removed. Second, all quarterly and semi-annual earnings forecasts were removed. This has been done to allow proper comparison between the compensation and earnings forecast data. Because the compensation data covers an entire fiscal year, it is more appropriate to compare the data to forecasts focusing on a similar period. Finally, an earnings forecast was only included in the dataset if compensation data was available for the respective year. This means that only those forecasts for which both the company and the respective year were included in the compensation data sample have been taken into account.

\subsection{Data analysis}

Hypothesis 1

To test the first hypothesis, a comparison is made between the type of targets in the compensation contracts and the measure used in the earnings forecasts. This is done for each of the type of forecast that occurs most frequently in the sample. Each of the variables have been coded as binary variables. For the dependent variable, variations of one compensation measure have also been grouped. For example: EPS, Income per Share (IPS) and EPS growth have been grouped as 'EPS target'. As a result, a value of 1 indicates the existence of a type of compensation target. Because the dependent variable in each of the regressions is binary variables, the method of analysis used to test this hypothesis is a logistic regression. The independent variables used in the analyses are binary variables that indicate whether a forecast uses a certain measure. For example, a value of one for the variable 'sales forecast' indicates that the company has published an earnings forecast which contains data about sales expectations. Types of forecasts that are similar in nature have been combined, such as EPS and GPS (fully reported EPS). Similarly, operating profit, earnings before tax and pre-tax income form one forecast variable: operating income. Six independent variables are regressed against each of the six dependent variables. The variables are: EPS, sales, gross margin, operating income, net income and Return on Equity (ROE). The measures are the same for both the dependent and independent variables. However, the dependent variables consist of compensation data, whereas the independent variables consist of forecast data. The general form of each of the regressions is as follows: 
Forecast measure $_{i}($ Yes $/$ No $)=\beta 0+\beta 1 *$ EPSForecast $+\beta 2 *$ SalesForecast $+\beta 3 *$

GrossMarginForecast $+\beta 4 *$ OperatingIncomeForecast $+\beta 5 *$ NetIncomeForecast $+\beta 6 *$ ROEForecast

Hypothesis 2

Whereas hypothesis 1 focuses on the type of variables used in both forecasts and compensation packages, this hypothesis focuses on the actual level of the variables. In essence, the question here is whether the level is the same when a company aligns their forecasts and compensation packages. To test this hypothesis, a multiple regression is used for each of the dependent variables. The dependent variable consists of the compensation level used by the company. The main independent variable used for the regressions are the forecasts that have been published by the company in the same fiscal year as the compensation contract. In the case that the company publishes a range instead of a specific point, the mid-point is taken. To be able to compare the variables, only firm years that contained values for both forecast levels and compensation target levels were included in the analysis. Furthermore, each of the regressions also include some control variables. One variable is used to control for firm size by taking the natural logarithm of the company's total assets. The six remaining control variables are dummy variables used to control for year. As a result, the general form of each of the regressions is as follows:

Forecast target $_{i}=\beta 0+\beta 1 *$ Compensation target $_{i}+\beta 2 *$ FirmSize $+\beta 3 *$ Year2007 $_{+}$ $\beta 4 *$ Year2008 $+\beta 5 *$ Year2009 $+\beta 6 *$ Year $2010+\beta 7 *$ Year $2011+\beta 8 *$ Year 2012

Due to the lack of data for four out of six variables, only EPS and sales targets were tested. Furthermore, both regressions require some modification to satisfy the nearly normal assumption. As a result, both the forecast target and compensation target in both regressions have been transformed by taking the natural logarithm of the variables. As a result, the final regression for both tests looks as follows:

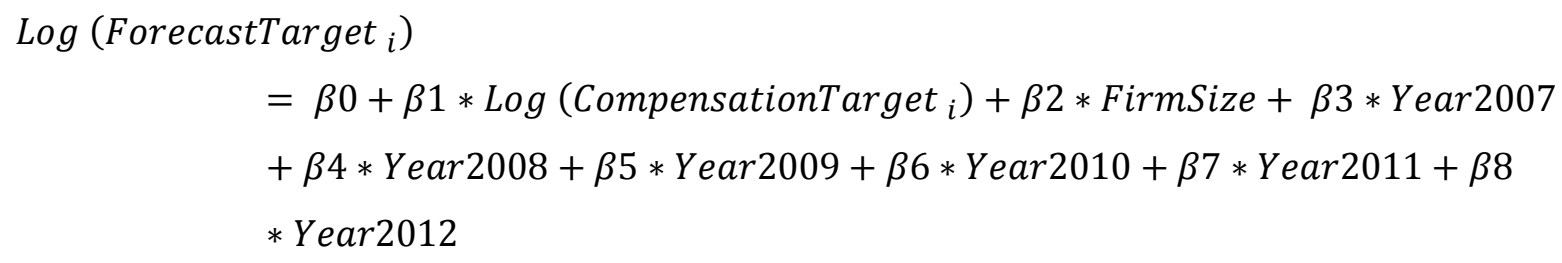

Hypothesis 3

Similar to the previous hypotheses, again a regression is used to analyse whether forecast frequency has an impact on the use of subjective or multiple measures in executive compensation contracts. Both the use of financial and non-financial measures and the use of multiple financial measures are used as dependent variables in the analysis. Because these variables are coded as binary variables, a logistic regression is used. The use of financial and non-financial measures is coded as 1 if the company uses at least one financial measure and one non-financial measure. Non-financial measures consist of both subjective measures such as customer satisfaction or individual goals and non-financial measures such as productivity or employee turnover. Multiple financial measures has been coded as 1 if the company uses two or more financial measures. As a result, it is possible that a company has a value of 1 on both 
variables in the same year. The independent variables consist of forecast frequency and several control variables. Forecast frequency is defined as the count of the number of forecasts made by a company in a specific year. Other included variables are firm size and binary variables for the years 2007 to 2012. Similar to the previous regressions this implies that the year 2006 serves as base line for the regression. The regression used for this hypothesis is as follows:

Use of subjective measure $($ Yes $/$ No $)=\beta 1 *$ Forecast Frequency $+\beta 2 *$ Firmsize $+\beta 3 *$ Year2007 $+\beta 4 *$ Year $2008+\beta 5 *$ Year2009 $+\beta 6 *$ Year $2010+\beta 7 *$ Year $2011+\beta 8 *$ Year2012

The use of multiple compensation measures is analysed using the same independent variables.

\section{Results}

This section discusses the results of the analyses.

A summary of the logistic regressions can be seen in table 1. The variable ROE target was not used as a dependent variable due to a lack of sufficient observations. As can be seen, the results of the analysis only partially support hypothesis one. The first logistic regression $(N=1954)$ shows a low $p$-value for both EPS forecasts $(p=0.001)$ and operating income forecasts $(p=0.052)$. Furthermore, the variable Gross margin forecast is moderately significant with a $p$-value of 0.074 . Due to the positive coefficient for EPS targets, it seems that companies that issue EPS forecasts are more likely to compensate their executives on EPS performance or a related measure.

Furthermore, the two moderately significant variables have a negative coefficient. This suggests that companies that publish operating income and gross margin forecasts do not tend to compensate their CEOs on EPS based measures. Because EPS forecasts is the only significant positive variable, the results of this regression are in line with $\mathrm{H} 1$.

\footnotetext{
$10 \mid$\begin{tabular}{l|l} 
Marble \\
Research
\end{tabular} Papers
} 
Table 1: Summary of Logistic Regression Analysis predicting Target Measures ( $N=1957)$

\begin{tabular}{|c|c|c|c|c|}
\hline $\begin{array}{l}\text { Dependent } \\
\text { variable }\end{array}$ & Independent variables & p-value & $\begin{array}{l}\text { Significant at } 5 \% \\
\text { level* }\end{array}$ & $\begin{array}{l}\text { Supports } \\
\text { H1? }\end{array}$ \\
\hline $\begin{array}{l}\text { EPS target } \\
\text { (yes/no) }\end{array}$ & $\begin{array}{l}\text { EPS forecast (yes/no), } \\
\text { Sales forecast (yes/no), } \\
\text { Gross margin forecast } \\
\text { (yes/no), } \\
\text { Operating income forecast } \\
\text { (yes/no), } \\
\text { Net income forecast (yes/no), } \\
\text { ROE forecast (yes/no). }\end{array}$ & $<0.001$ & EPS forecast $(+)$ & Yes \\
\hline $\begin{array}{l}\text { Sales target } \\
\text { (yes/no) }\end{array}$ & Idem & $<0.001$ & $\begin{array}{l}\text { EPS forecast }(+), \\
\text { Sales forecast }(+), \\
\text { Gross margin } \\
\text { forecast }(+) \text {, income } \\
\text { Operating } \\
\text { forecast }(+) \text {. }\end{array}$ & Partially \\
\hline $\begin{array}{l}\text { Gross margin } \\
\text { target (yes/no) }\end{array}$ & Idem & $<0.001$ & None & No \\
\hline $\begin{array}{l}\text { Operating } \\
\text { income target } \\
\text { (yes/no) }\end{array}$ & Idem & $<0.001$ & $\begin{array}{l}\text { EPS Forecast }(-) \text {, } \\
\text { Sales forecast }(-) \text {, } \\
\text { Operating income } \\
\text { forecast }(+) \text {, } \\
\text { Net income forecast } \\
(+) \text {. }\end{array}$ & Partially \\
\hline $\begin{array}{l}\text { Net income } \\
\text { target (yes/no) }\end{array}$ & Idem & $<0.001$ & $\begin{array}{l}\text { EPS forecast }(+), \\
\text { Gross margin } \\
\text { forecast }(+) .\end{array}$ & No \\
\hline
\end{tabular}

For the second regression, a sales related compensation target replaced an EPS related target as dependent variable. The results of this test are mixed. First, the existence of sales forecasts have a significant positive effect on the

existence of sales related targets in compensation contracts $(p<0.001)$. This is in accordance to $\mathrm{H} 1$. However, EPS forecasts, gross margin forecasts and to a lesser extent operating income forecasts were found to have a similar effect. More surprisingly is the coefficient of gross margin forecasts, which exceeds the coefficient of sales forecasts. Based on the results of this regression, there is some evidence that companies compensate their CEOs on the same measures as the measures used in earnings forecasts. However, it is not possible to conclude that sales forecasts are the dominant predictor of the use of sales targets as compensation measures. Therefore, this regression provides only partial support for $\mathrm{H} 1$.

The third regression uses gross margin targets as dependent variable. The results show no significant results for any of the independent variables. As a result, this regression does not support $\mathrm{H} 1$.

The fourth regression focuses on the use of operating income targets. Four out of six independent variables yielded significant results. Both EPS and sales forecasts have significant negative coefficients ( $p<0.001$ and $p=0.049$ respectively). This suggests that companies do not use operating income as a 
compensation measure when they have published EPS or sales forecasts. These results correspond with the expectation of $\mathrm{H} 1$. Operating income forecasts have a significant positive effect $(p<0.001)$ on the use of operating income in compensation contracts. This result also supports $\mathrm{H} 1$. However, net income forecasts were also positively related to the dependent variable. Furthermore, the coefficient of this variable exceeds that of operating income forecasts. Therefore, it appears that the publication of net income forecasts, relative to operating income forecasts, is more closely related to the use of operating income targets. These results contradict $\mathrm{H} 1$. As a result, the results of this regression only partially support $\mathrm{H} 1$.

Finally, the regression that uses net income targets as dependent variable also does not provide any support for $\mathrm{H} 1$. Although the use of sales forecasts had a moderately significant, negative effect ( $p=$ 0.056) on the use of net income targets, both EPS and gross margin forecasts were significant and positive ( $p<0.001$ for both variables). In addition, the variable net income forecast was insignificant at a $5 \%$ level. These results are not in line with $\mathrm{H} 1$.

In general, these results show that in only one case the regression fully supports $\mathrm{H} 1$. In addition, three of the regressions find no evidence for H1. Finally, one regression provides partial support. As a result, there is insufficient evidence to either fully reject or fail to reject the hypothesis. This leads to the conclusion that $\mathrm{H} 1$ is partially supported.

Table 2 and 3 summarize the results of the tests for $\mathrm{H} 2$. Because a lot of companies do not publish specific targets, it was not possible to test each of the variables that were used to test $\mathrm{H} 1$.

Table 2: Regression of Log (EPS target) against Firm size, year and Log (EPS forecast)

\begin{tabular}{|c|c|c|c|c|c|c|c|}
\hline Variable & B & SE & \multicolumn{2}{|c|}{$95 \%$ CI } & $\boldsymbol{\beta}$ & $t$ & $\boldsymbol{p}$ \\
\hline Constant & 0,266 & 0,131 & 0,008 & 0,525 & & 2,04 & 0,044 \\
\hline Firm size & 0,03 & 0,015 & $-0,001$ & 0,06 & 0,054 & 1,94 & 0,054 \\
\hline 2007 & $-0,522$ & 0,102 & $-0,723$ & $-0,321$ & $-0,159$ & $-5,14$ & $<0,001$ \\
\hline 2008 & $-0,207$ & 0,088 & $-0,381$ & $-0,033$ & $-0,094$ & $-2,36$ & 0,02 \\
\hline 2009 & $-0,105$ & 0,093 & $-0,288$ & 0,078 & $-0,041$ & $-1,13$ & 0,259 \\
\hline 2010 & $-0,264$ & 0,087 & $-0,436$ & $-0,092$ & $-0,136$ & $-3,04$ & 0,003 \\
\hline 2011 & $-0,267$ & 0,089 & $-0,443$ & $-0,09$ & $-0,134$ & $-2,99$ & 0,003 \\
\hline 2012 & $-0,257$ & 0,089 & $-0,434$ & $-0,08$ & $-0,13$ & $-2,88$ & 0,005 \\
\hline $\begin{array}{l}\text { Log (EPS } \\
\text { forecast) }\end{array}$ & 0,808 & 0,023 & 0,763 & 0,853 & 0,938 & 35,41 & $<0,001$ \\
\hline
\end{tabular}

Note: $\operatorname{Adj} . R^{2}=, 9289(N=159, p<0,001)$.

Although limited by a relatively low amount of observations ( $N=159$ and 78 respectively), EPS and sales forecast levels were compared to their respective compensation levels. The compensation target levels for EPS was significant and positive $(p<0.001, B=0.808)$. The downside of taking the logarithm

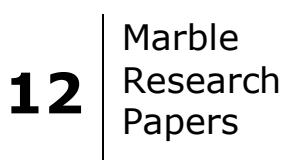


of both the sales and compensation targets is that the variables can no longer be interpreted in their original values. In the current situation, a one percent change in EPS forecasts increases the EPS compensation target by roughly $0.807 \%$. Furthermore, the $95 \%$ confidence interval of the variable ranges from 0.763 to 0.853 . As a result, it can be concluded that EPS forecast levels do not move oneon-one with the EPS compensation target levels. This suggests that companies tend to set relatively lower EPS compensation target levels in comparison to the forecast levels, which is in line with $\mathrm{H} 2$. For the remaining variables, the percent change in the dependent variable can be found by taking the exponent of the coefficient (UCLA: Statistical Consulting Group, n.d.). Except for the year 2009, all remaining variables are significant. Firm size is moderately significant with a p-value of 0.052 . Therefore, the EPS based target is likely to increase as the firm grows larger, all else being equal. Furthermore, it appears that the EPS based targets in compensation contracts have decreased relative to the base line 2006, because all year dummy variables have negative coefficients.

Table 3 shows the results of the regression involving sales targets. Similar to the previous regression, sales forecast levels is found to be a significant predictor of sales compensation targets $(p<0.001, \mathrm{~B}=$ 1.006). However, in contrast to the first regression, sales compensation targets appear to increase by almost the same percentage as the percentage increase in sales forecast levels. An increase of $1 \%$ in forecast level increases the compensation target by $1.006 \%$. This result contradicts the expectation raised in $\mathrm{H} 2$. Furthermore, it is also not possible to conclude that the increase in compensation target outpaces the increase in forecast level. This is because the $95 \%$ confidence interval of the coefficient ranges from 0.927 to 1.085 . Therefore, the only conclusion that can be drawn from these results is that the compensation targets do not differ significantly from the forecast levels. Another interesting result is the increase in sales compensation targets in 2009. All else equal, sales compensation targets were roughly $26 \%$ higher in 2009 compared to 2006 . This is remarkable because it is the only significant increase throughout the years 2007 to 2012.

Table 3: Regression of Log (Sales target) against Firm size, Year and Log (Sales forecast)

\begin{tabular}{lccccccc} 
Variable & $\mathbf{B}$ & $\mathbf{S E}$ & \multicolumn{2}{c}{$\mathbf{9 5 \%} \mathbf{C I}$} & $\boldsymbol{\beta}$ & $\boldsymbol{t}$ & $\boldsymbol{p}$ \\
\hline Constant & 0,309 & 0,102 & 0,106 & 0,511 & & 3,04 & 0,003 \\
Firm size & $-0,051$ & 0,043 & $-0,137$ & 0,035 & $-0,049$ & $-1,19$ & 0,238 \\
2007 & 0,064 & 0,073 & $-0,082$ & 0,209 & 0,017 & 0,87 & 0,386 \\
2008 & 0,055 & 0,07 & $-0,084$ & 0,194 & 0,017 & 0,79 & 0,431 \\
2009 & 0,234 & 0,104 & 0,027 & 0,441 & 0,029 & 2,25 & 0,027 \\
2010 & 0,043 & 0,073 & $-0,102$ & 0,188 & 0,011 & 0,59 & 0,559 \\
2011 & 0,076 & 0,075 & 0,073 & 0,225 & 0,018 & 1,02 & 0,314 \\
2012 & 0,037 & 0,068 & $-0,099$ & 0,174 & 0,014 & 0,54 & 0,589 \\
Log & & & & & & & \\
(Sales & & & & & & & \\
forecast) & 1,006 & 0,04 & 0,927 & 1,085 & 1,049 & 25,27 & $<0,001$ \\
\hline
\end{tabular}

Note: Adj. $R^{2}=, 993(N=78, p<0,001)$.

Based on these two regressions, $\mathrm{H} 2$ is partially supported. Although companies tend to increase their EPS compensation targets at a lower rate than their EPS forecast levels, this is not the case for sales based targets and forecasts.

Tables 4 and 5 show the results for H3. The main result from both regressions is that neither the use of a combination of financial and non-financial measures nor the use of multiple financial compensation measures is significantly influenced by the forecast frequency of a firm. The first regression, as seen in table 4 , is insignificant at the regression level $(N=422, p=0.585)$. Although the second regression is 
significant at a $5 \%$ level $(N=422, p=0.029)$, forecast frequency does not have a significant impact on the use of multiple financial measures. As a result, $\mathrm{H} 3$ is rejected. Other interesting results are that firm size has a negative coefficient in both regressions. This implies that, relative to smaller firms, larger firms are less likely to use subjective and multiple compensation measures. The last notable result of this analysis is the increase in the use of multiple measures over the years. With the exception of 2007, all fiscal years saw a significant increase in the use of multiple compensation measures relative to the base line 2006. The fact that the coefficients are increasing suggests that companies increasingly have started to use multiple financial measures.

Table 4: Logistic regression of use of both financial and non-financial compensation measures against forecast frequency and control variables.

\begin{tabular}{|c|c|c|c|c|c|c|}
\hline Variable & B & SE & $\boldsymbol{p}$ & OR & \multicolumn{2}{|c|}{$95 \%$ CI } \\
\hline Constant & $-1,697$ & 1,196 & 0,156 & 0,183 & 0,018 & 1,912 \\
\hline Firm size & $-0,16$ & 0,152 & 0,292 & 0,852 & 0,633 & 1,147 \\
\hline 2007 & $-0,066$ & 0,94 & 0,944 & 0,936 & 0,148 & 5,913 \\
\hline 2008 & 0,828 & 0,812 & 0,308 & 2,288 & 0,466 & 11,247 \\
\hline 2009 & 0,536 & 0,847 & 0,527 & 1,709 & 0,325 & 8,989 \\
\hline 2010 & 1,046 & 0,824 & 0,204 & 2,848 & 0,566 & 14,326 \\
\hline 2011 & 0,673 & 0,85 & 0,428 & 1,961 & 0,371 & 10,377 \\
\hline 2012 & 0,672 & 0,875 & 0,442 & 1,959 & 0,353 & 10,885 \\
\hline $\begin{array}{l}\text { Forecast } \\
\text { frequency }\end{array}$ & $-0,03$ & 0,034 & 0,389 & 0,971 & 0,907 & 1,039 \\
\hline
\end{tabular}

Note: Confidence interval for Odds Ratio.

Table 5: Logistic regression of use of multiple financial compensation measures against forecast frequency and control variables.

\begin{tabular}{lcccccc}
\multicolumn{1}{c}{ Variable } & B & SE & P & OR & \multicolumn{2}{c}{$\mathbf{9 5 \%}$ CI } \\
\hline Constant & 0,302 & 0,823 & 0,635 & 1,352 & 0,389 & 4,703 \\
Firm size & $-0,167$ & 0,463 & 0,044 & 0,546 & 0,72 & 0,995 \\
2007 & $-0,003$ & 0,43 & 0,996 & 0,997 & 0,403 & 2,471 \\
2008 & 0,873 & 0,44 & 0,042 & 2,395 & 1,031 & 5,565 \\
2009 & 0,779 & 0,452 & 0,077 & 2,18 & 0,92 & 5,168 \\
2010 & 0,949 & 0,448 & 0,036 & 2,584 & 1,066 & 6,262 \\
2011 & 0,967 & 0,462 & 0,031 & 2,63 & 1,093 & 6,324 \\
2012 & 1,056 & 0,018 & 0,022 & 2,874 & 1,161 & 7,114 \\
Forecast frequency & 0,001 & 0,636 & 0,959 & 1,001 & 0,966 & 1,037 \\
\hline
\end{tabular}

Note: Confidence interval for Odds Ratio.

\section{Discussion}

Based on the analysis presented above, the first hypothesis is only partially supported. First, the use of EPS compensation measures is significantly influenced by the publication of EPS forecasts. This is in accordance with $\mathrm{H} 1$ and suggests that companies tend to use the same measures for forecasts and compensation contracts. A similar result has been obtained for sales and operating income compensation measures. The use of both measures increases as the use of these measures in forecasting increases. However, both sales and operating income compensation measures were also influenced by other factors. For example, sales targets were also positively influenced by the use of EPS, gross margin and net income forecasts. The coefficients of some of the other types of forecasts were larger or equally 
large as the coefficient of sales forecasts. This suggests that the use of sales forecasts was not the primary predictor of the use of sales targets. Similarly, the publication of net income forecasts is positively related to the use of operating income compensation measures. However, a possible explanation for this finding is that the two measures are relatively similar. The main difference is the incorporation of tax in net income measures, which can not be influenced by a company. Depending on the specific operating income measures, other differences include the inclusion of depreciation, interest or amortization.

Finally, the use of ROE forecasts did not appear to significantly affect any of the dependent variables. The most likely explanation for the lack of results here is the lack of sufficient forecasts included in the sample. To verify if the use of such forecasts influence the use of ROE compensation measures the same tests should be performed with a larger sample.

Similar to the first hypothesis, the analysis of $\mathrm{H} 2$ yields mixed results. First, the results show that both EPS and sales based compensation target levels are positively related to EPS and sales based forecast levels respectively. This is no surprise, because companies generally adapt their performance targets if their performance has changed over the years. However, the rate of change by which this adaptation occurs leads to some interesting results. Initially, the expectation was that the compensation target levels will be slightly lower than the forecasting levels.

The results from the first regression as seen in table 2 only partially support this hypothesis. On the one hand, the rate of change of EPS compensation and EPS forecasts differ significantly. More specifically, a $1 \%$ increase in EPS forecast results, all else being equal, in a $0.807 \%$ increase in the EPS compensation target. Multiple explanations can be offered why companies use lower compensation targets. One explanation for this result can be found in the research findings by Bergman and Roychowdhury (2008), who found that companies tend to introduce a positive bias in their forecasts. As a result, it can be expected that companies take this bias into account when designing compensation contracts. This results in a more realistic compensation target for the CEO. A second explanation is that companies want to avoid providing incentives for earnings management. If executives have to meet targets that are difficult to meet in order to earn a bonus, it is possible that they will attempt to manipulate data to achieve the expectations. Finally, it is also possible that the compensation committee is influenced by the executive and therefore sets lower compensation targets. The last remarkable result of this regression is the decrease in the height of EPS compensation targets after 2006. Except for 2009, all year variables have significant negative coefficients. These results can be explained in a similar way as the relation between EPS target levels and forecast levels. It is possible that relative to 2006, compensation committees increasingly recognize the bias that is included in the earnings forecasts. However, it is also possible that these committees increasingly succumb to the pressure of management to set easy-to-achieve targets.

On the other hand, a regression using sales compensation targets did not support the hypothesis. The results from this analysis do not provide evidence that the change in sales target is significantly different from the change in sales forecasts. Although future research should investigate the true result, a potential cause for this result can be offered. The insignificant result obtained in this research could be caused by a lack of communication between the executive team and the compensation committee. The 
executive team is responsible for publishing management earnings forecasts, whereas the compensation committee designs the compensation contracts. If the committee is not aware of the existence of bias in the earnings forecasts, they may use the expectations of these forecasts as targets for the compensation contracts without considering the consequences.

Finally, both regressions that focused on forecasting frequency did not yield significant results for the use of financial and non-financial measures or multiple financial measures. This was contrary to the expectations of hypothesis 3. As a result, both $\mathrm{H} 3.1$ and $\mathrm{H} 3.2$ are rejected at a $5 \%$ level. A possible explanation for the lack of results is that at a certain point, an additional earnings forecast no longer adds significant value to shareholders. As a result, companies that wish to increase their reputation for transparency might not issue additional forecasts while improving the transparency of other elements of the business. In addition, it is possible that the companies that were included in this sample released a larger amount of earnings forecasts for other reasons than the desire to create or maintain a reputation for transparency. The significant influence of firm size on both variables is also of interest. The larger the firm size in terms of total assets, the less likely a firm uses both non-financial and multiple measures. A possible explanation for this observation is that larger firms are under more stringent scrutiny by regulatory bodies and shareholders. These stakeholders may disapprove on the use of subjective measures, which were also included in the non-financial measures. Finally, the results show that companies have increasingly started to use multiple financial measures in compensation packages. Relative to the base line 2006, the coefficients are both positive and increasing. It is possible that companies have recognized the preference for such packages by shareholders and have adjusted them accordingly.

\section{Conclusion}

Information asymmetry poses an important issue for stakeholders. Until recently, it was difficult to obtain detailed information on the compensation of board of directors and executives of a company. New regulations by the SEC, introduced in 2006, forces U.S. listed companies to publish information on their compensation practices. These are expected to increase the transparency of companies. Another way to reduce information asymmetry is by publishing management earnings forecasts. These forecasts detail the expectations of the company with respect to its future performance. This research builds on the new SEC regulations by using the compensation information published by listed companies and comparing them to the information included in management earnings forecasts.

Three conclusions can be drawn from the analysis. First, it appears that companies generally do not align the measures used for earnings forecasts and compensation contracts. Only the use of EPS, sales and operating income forecasts were found to be significant predictors of their respective targets. Therefore, an implication for practice that can be drawn from this research is that companies may be able to improve their ability to meet their forecast expectations if they align the measures used for earnings forecasts and compensation contracts. Second, companies do not always use lower goals relative to the expectations in earnings forecasts, despite the existence of a positive bias in the latter. From the results, this was only the case for EPS targets, but not for sales compensation targets. An implication of this result is that companies should revaluate their compensation contracts if they

\footnotetext{
Marble

16 Research

Papers
} 
introduce a bias in their earnings forecasts. Contracts with difficult to reach targets may cause executives to resort to earnings management in order to obtain a bonus. Finally, it appears companies who issue earnings forecasts are not more likely to use subjective or multiple measures. This is contrary to the expectation raised in this paper. Assuming companies that release earnings forecasts actively strive to reduce information asymmetry or increase their transparency and thus meet the demands of their shareholders, the use of subjective or multiple compensation targets may help them further achieve this goal.

With respect to limitations, this research is limited in a number of ways. First, it is limited due to its exploratory nature. As a result, the availability of previous literature on the same topic is fairly limited. Therefore, further research can investigate the strength of the theory used in this research to build the hypotheses. Furthermore, this study only establishes some relationships between the two topics of interests. Although some explanations for the results are offered in the discussion section, these are not empirically tested. This is a possible topic for future research. In addition, this study provides no evidence for causality between management earnings forecasts and executive compensation contracts. In this paper, it is assumed that management earnings forecasts influence compensation contracts as the publication of such forecasts generally precedes the creation of compensation contracts. However, future research should investigate the appropriateness of this assumption. Furthermore, the sample size used to test $\mathrm{H} 2$ is rather small. Therefore, future research can replicate the analysis performed in this paper with a larger sample size to determine the external validity of these findings. This research is also limited in terms of scope, as it only covers a limited amount of forecasts in terms of the measure used. For example, the use of Return on Equity and capital expenditures as forecast types were not included due to a lack of data. As a result, a suggestion for future research is to focus on these variables to investigate whether they show a similar pattern as the results obtained in this study. Finally, it is likely that not all relevant independent variables were identified and included in this research. To further investigate the relationship between management earnings forecasts and executive compensation contracts, future research can attempt to identify missing variables. 
List of references

Ajinkya, B., Bhojraj, S., \& Sengupta, P. (2005). The Association between outside Directors, Institutional Investors and the Properties of Management Earnings Forecasts. Journal of Accounting Research, 43(3), 343-376. doi: 10.2307/3542289

Baginski, S. P., \& Hassell, J. M. (1990). The Market Interpretation Of Management Earnings Forecasts. The Accounting Review, 65(1), 175.

Bergman, N. K., \& Roychowdhury, S. (2008). Investor sentiment and corporate disclosure. Journal of Accounting Research, 46(5), 1057-1083.

CFA Institute. (2006). Breaking the Short-Term Cycle: Discussion and Recommendations on How Corporate Leaders, Asset Managers, Investors, and Analysts Can Refocus on Long-Term Value. Charlottesville, VA: CFA Institute.

Chen, S. (2004). Why do managers fail to meet their own forecasts? Paper presented at the 14th Annual Conference on Financial Economics and Accounting (FEA).

Coller, M., \& Yohn, T. L. (1997). Management Forecasts and Information Asymmetry: An Examination of Bid-Ask Spreads. Journal of Accounting Research, 35(2), 181-191. doi: 10.2307/2491359

Diamond, D. W., \& Verrecchia, R. E. (1991). Disclosure, liquidity, and the cost of capital. The journal of Finance, 46(4), 1325-1359.

Donahue, S. M. (2008). Executive compensation: the new executive compensation disclosure rules do not result in complete disclosure. Fordham Journal of Corporate \& Financial Law, 13(1), 59.

Frankel, R., McNichols, M., \& Wilson, G. P. (1995). Discretionary Disclosure and External Financing. The Accounting Review, 70(1), 135-150. doi: 10.2307/248392

Frantz, P., Instefjord, N., \& Walker, M. (2013). Executive Compensation: A Model of Disclosure Choice. Journal of Business Finance \& Accounting, 40(9-10), 1184-1220. doi: 10.1111/jbfa.12041

Gore, P., Pope, P. F., \& Singh, A. K. (2007). Earnings management and the distribution of earnings relative to targets: UK evidence. Accounting and business research, 37(2), 123-149. doi: 10.1080/00014788.2007.9730065

Graham, J. R., Harvey, C. R., \& Rajgopal, S. (2005). The economic implications of corporate financial reporting. Journal of Accounting and Economics, 40(1), 3-73.

Hassell, J. M., Jennings, R. H., \& Lasser, D. J. (1988). Management Earnings Forecasts: Their Usefulness As A Source. The Journal of Financial Research, 11(4), 303.

Hirst, D. E., Koonce, L., \& Venkataraman, S. (2007). How disaggregation enhances the credibility of management earnings forecasts. Journal of Accounting Research, 45(4), 811-837. doi: 10.1111/j.1475-679X.2007.00252

Hirst, D. E., Koonce, L., \& Venkataraman, S. (2008). Management earnings forecasts: a review and framework. Accounting horizons, 22(3), 315-338. doi: 10.2308/acch.2008.22.3.315

Hutton, A. P., \& Stocken, P. C. (2007). Effect of Reputation on the Credibility of Management Forecasts.

Johnson, M. F., Kasznik, R., \& Nelson, K. K. (2001). The impact of securities litigation reform on the disclosure of Forward-Looking information by high technology firms. Journal of Accounting Research, 39(2), 297-327.

Jusoh, R., Ibrahim, D. N., \& Zainuddin, Y. (2008). The performance consequence of multiple performance measures usage. International Journal of Productivity and Performance Management, 57(2), 119+-136. doi: doi:10.1108/17410400810847393

18 Research

Papers 
Karamanou, I., \& Vafeas, N. (2005). The Association between Corporate Boards, Audit Committees, and Management Earnings Forecasts: An Empirical Analysis. Journal of Accounting Research, 43(3), 453-486. doi: 10.1111/j.1475-679X.2005.00177.x

Kasznik, R. (1996). On the association between voluntary disclosure and earnings management. Available at SSRN 15062.

Kim, D. S., \& Yang, J. (2010). Beating the target: A closer look at annual incentive plans. Unpublished working paper, Indiana University.

Kim, S., \& Shin, J. Y. (2014). Executive Bonus Target Ratcheting: Evidence from the New Executive Compensation Disclosure Rule. Available at SSRN 247911.

King, R., Pownall, G., \& Waymire, G. (1990). Expectations adjustment via timely management forecasts: review, synthesis, and suggestions for future research. Journal of Accounting Literature, 9, 113.

Kohn, A. H., \& Fisher, J. (2007). The materiality of performance targets. Insights: The Corporate \& Securities Law Advisor, 21(10), 2.

König, E. (2012, March 1). Directeur Vestia kreeg 3,5 miljoen euro mee bij vertrek. NRC. Retrieved from http://www.nrc.nl/nieuws/2012/03/01/directeur-vestia-kreeg-35-miljoen-euro-mee-bij-vertrek/

Lansford, B., Lev, B., \& Tucker, J. W. (2007). Why do firms issue disaggregated earnings guidance? The archival evidence. AAA 2008 Financial Accounting and Reporting Section (FARS).

Longnecker, B., \& Krueger, J. (2007). The Next Wave of Compensation Disclosure. Compensation \& Benefits Review, 39(1), 50-54. doi: 10.1177/0886368706297432

Marquardt, C. A., \& Wiedman, C. I. (1998). Voluntary Disclosure, Information Asymmetry, and Insider Selling through Secondary Equity Offerings*. Contemporary accounting research, 15(4), 505537. doi: 10.1111/j.1911-3846.1998.tb00569.x

Nagar, V., Nanda, D., \& Wysocki, P. (2003). Discretionary disclosure and stock-based incentives. Journal of Accounting and Economics, 34(1-3), 283-309. doi: http://dx.doi.org/10.1016/S01654101(02)00075-7

National Investor Relations Institute. (2006). NIRI Issues 2006 Survey Results on Earnings Guidance Practices. Retrieved April 24, 2015, from http://www.niri.org/OtherContent/alerts/ea060406cfm.aspx

Pownall, G., Wasley, C., \& Waymire, G. (1993). The Stock Price Effects of Alternative Types of Management Earnings Forecasts. The Accounting Review, 68(4), 896-912. doi: 10.2307/248512

Rogers, J. L., \& Stocken, P. C. (2005). Credibility of Management Forecasts. The Accounting Review, 80(4), 1233-1260. doi: 10.2307/4093123

Thompson, M. (2013). HSBC CEO made $\$ 11$ million in scandal-hit year. CNNMoney. Retrieved from http://money.cnn.com/2013/03/04/news/companies/hsbc-ceo-pay/

UCLA: Statistical Consulting Group. (n.d.). How do I interpret a regression model when some variables are log transformed? Retrieved June, 2015, from http://www.ats.ucla.edu/stat/mult_pkg/faq/general/log_transformed_regression.htm

v.d. Hulst, A. (2015, March 20). Ook ABN-Amro verhoogt de salarissen van de bestuurders. NRC. Retrieved from http://www.nrc.nl/carriere/2015/03/20/ook-abn-amro-verhoogt-de-salarissenvoor-de-bestuurders/

Weiner, N., \& Mahoney, T. A. (1981). A model of corporate performance as a function of environmental, organizational, and leadership influences. Academy of Management Journal, 24(3), 453-470. 
Yhim, H.-p., Karim, K. E., \& Rutledge, R. W. (2003). The association between disclosure level and information quality: voluntary management earnings forecasts. Applied Financial Economics, 13(9), 677-692. doi: 10.1080/09603100210138538 